\title{
HYDROGEL BASED ON CROSSLINKED METHYLCELLULOSE PREPARED BY ELECTRON BEAM IRRADIATION FOR WOUND DRESSING APPLICATION
}

\author{
Ambyah Suliwarno \\ Center of Isotopes and Radiation Application-National Nuclear Energy Agency (BATAN) \\ Jl. Lebak Bulus Raya No 49 Jakarta 12440, Indonesia
}

Received May 19, 2014; Accepted August 18, 2014

\begin{abstract}
The aim of this research is to explore the possibility of methylcellulose polymer to be used as wound dressing material prepared using electron beam technique. The methylcellulose paste solution with various of molecular weight (SM-4, SM-100, SM-400, SM-4000 and SM-8000) at different concentration (15-30\% w/v) were irradiated by using electron beam on the dose range of $10 \mathrm{kGy}$ up to $40 \mathrm{kGy}$. Gel fraction and swelling ratio of hydrogels were determined gravimetrically. Tensile strength and elasticity of hydrogels were measured using a universal testing machine. It was found that with the increasing of irradiation dose from 10 up to $40 \mathrm{kGy}$, gel fraction and tensile strength were increased for all of hydrogels with various of molecular weight. On contrary, the swelling ratio of hydrogels decreased with increasing of irradiation dose. The optimum hydrogels elasticity were obtained from methylcellulose solution with the concentration range of $15-20 \%$ with irradiation dose of $20 \mathrm{kGy}$ and showed excellent performance. The hydrogels based on methylcellulose prepared by electron beam irradiation can be considered for wound dressing material.
\end{abstract}

Keywords: methylcellulose; molecular weight; electron beam irradiation; wound dressing

\section{ABSTRAK}

Penelitian ini bertujuan untuk menyelidiki kemungkinan polimer metilselulosa untuk digunakan sebagai bahan pembalut luka, yang dibuat dengan menggunakan teknik berkas elektron. Larutan pasta metilselulosa dari berbagai berat molekul (SM-4, SM-100, SM-400, SM-4000 dan SM-8000) pada konsentrasi yang berbeda (15-30\% w/V) diiradiasi dengan berkas elektron pada rentang variasi dosis antara 10 kGy hingga 40 kGy. Fraksi gel dan rasio pengembangan hidrogel ditentukan secara gravimetri. Kekuatan tarik dan elastisitas hidrogel diukur dengan menggunakan mesin uji universal. Pengamatan menunjukkan bahwa dengan meningkatnya dosis iradiasi dari 10 hingga 40 kGy, fraksi gel dan kekuatan tarik hidrogel meningkat untuk semua berat molekul. Sebaliknya, rasio pengembangan hidrogel menurun dengan pertambahan dosis iradiasi. Elastisitas hidrogel yang optimum diperoleh dari larutan pasta metilselulosa dengan rentang variasi konsentrasi $15-20 \%$ pada iradiasi dosis 20 kGy dan menunjukkan penampilan yang sangat baik. Hidrogel metilselulosa yang dibuat dengan teknik iradiasi berkas elektron dapat dipertimbangkan untuk digunakan sebagai bahan pembalut luka.

Kata Kunci: metilselulosa; berat molekul; iradiasi berkas elektron; pembalut luka

\section{INTRODUCTION}

Methylcellulose is a hydrophilic cellulose derivative wherein a methylene group attached by ether bond group on anhydrous glucose ring. It is a white powder that is soluble in cold water, but not soluble in hot water. Most of methylcellulose with water as the solvent for a wide range of usage and has a degree of substitution (DS) between 1.4 and 2.0. Methylcellulose with high DS values of between 2.4 to 2.8 is not soluble in water, but soluble in organic compounds. In general properties of methyl cellulose is determined by the level and distribution DS methoxy group on the glucose ring with the structure in Fig. 1a [1-2]. Hydrogels are hydrophilic three-dimensional (3D) networks that are chemically crosslinked or physically entangled with excellent water swelling capacity (Fig. 1b), by using covalent bonds to the network system is a permanent material. It is resistant to the solvent, and the only type of hydrogel can be broken down or damaged by chemical reaction and mechanical pressure. As mentioned above that the hydrogel is composed of mostly water as a main component to allow for the penetration of compounds or solvents of low molecular weight [5]. Hydrogels are characterized as soft material with high water content, which is similar to soft tissue, so they have good biocompatible properties and have been exploited in many fields such as food additives, pharmaceuticals, cell

* Corresponding author.

Email address : ambyahs@batan.go.id 


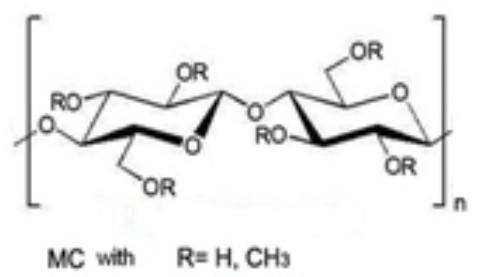

(a)

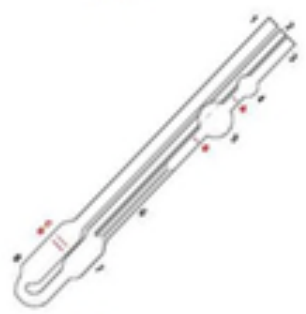

(c)

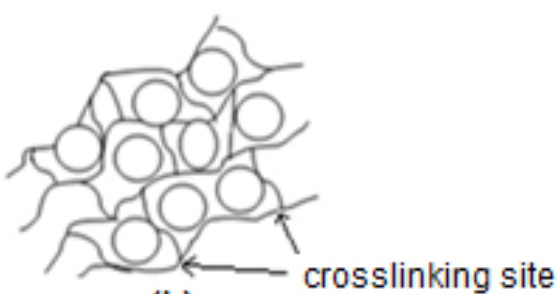

(b)

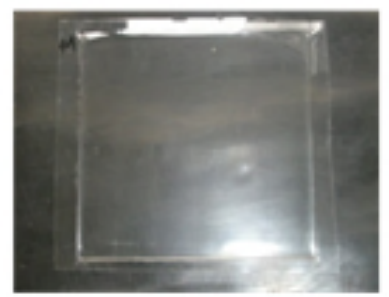

(d)

Fig 1. (a) Methylcellulose structure is the repeating unit of cellulose with $\mathrm{R}=\mathrm{H}, \mathrm{CH}_{3}$ [1], (b) Illustration of swollen state, water molecules (O) trapped in a 3-dimensional network of hydrogels [9], (c) Ubbelohde viscometer apparatus [8], and (d) Photograph of the film sample of methylcellulose gel against a black background

culture, biomedical implants and wound dressing [5]. Wound dressing is an artificial skin that can meet the requirements such as higher vapor or gas permeation. Wound dressings can perform several functions; provide physical support to a wound, remove necrotic or contaminated tissue from the wound, deliver medication and absorb exudates without allowing excessive fluid loss. As a wound dressing, hydrogels properties such as good biocompatibility, hydrophilicity and capability of swell in water or biological fluids are required in several biomedical and pharmaceutical applications. Recently, some type of hydrogels which are used in wound dressings include; poly(vinyl alcohol)/(PVA), poly(vinylpyrrolidone) and polysaccharide derivatives [6]. With the right choices of hydrogels used for these fibrous materials, they could enhance the healing of wounds significantly compared with the conventional fibrous dressing materials, such as gauze. These bandages could be made such that they contain bioactive ingredients, such as antimicrobial, antibacterial, and anti inflammatory agents, which could be released to the wounds enhancing their healing [7]. Determination of methylcellulose's molecular weight was performed by using Ubbelohde viscometer (Fig. 1c), which is recommended for cellulose polymer solution with higher viscosity that based on the ASTM D 445 standard. Ubbelohde viscometer is closely related to that of the Ostwald, in which the liquid is inserted into the reservoir, and then aspirated through the capillary channel to the limit and then streamed and recorded its flow time. It has three arms extending from the tip of the capillary and is open to atmosphere. In this method the pressure head depends only on a fixed height, and is not affected by the total fluid volume [8].

\section{EXPERIMENTAL SECTION}

This research has been done at the Environmental Polymer group Laboratory of Environmental and Industrial Materials Research Division-Japan Atomic Energy Agency, Takasaki, Japan.

\section{Materials}

Five types of methylcellulose powder, namely; SM-4, SM-100, SM-400, SM-4000 and SM-8000 were purchased from Shin-Etsu Co. (Japan), as the main ingredient for preparation the paste solution and gels. Demineralization distilled water is used as solvent, and polypropylene (PP) film sheets were used in vacuum packaging of paste solution.

\section{Instrumentation}

Ubbelohde viscometer was used in determination of methylcellulose solution's viscosity at $20^{\circ} \mathrm{C}$. Cockcroft Walton type of Electron accelerator NHV 2MeV, $30 \mathrm{~mA}$ at Takasaki Advanced Radiation Research Institute-Japan Atomic Energy Agency, Takasaki, Japan. Centrifuge apparatus with tightly lidded container (cup and cover), which is $150 \mathrm{~mL}$ capacity. Pressing machine tools for preparation the paste and vacuum packaging machine for the paste proper to irradiation, then an analytical balance for quantitatively weighing. 


\section{Procedure}

\section{Preparation of hydrogels}

Several amount of $150 \mathrm{~mL}$ paste solution of methylcellulose of SM-4, SM-100, SM-400, SM-4000 and SM-8000 were prepared by adding a amount of water into the methylcellulose powder which placed in a cup for concentrations of 15,20 , and $30 \%(w / v)$, respectively. The paste solution in a closed cup was performed a centrifuge at $2500 \mathrm{rpm}$ for $10 \mathrm{~min}$, and then stored in refrigerator at $12{ }^{\circ} \mathrm{C}$ overnight. Film paste is made by pressing the paste solution packed by PP films by using a press machine on a pressure of $150 \mathrm{~kg} / \mathrm{cm}^{2}$ at room temperature, then followed by vacuum packing sealed. The film paste having a size of; $16 \mathrm{~cm} \times 16 \mathrm{~cm}$ with a thickness of $1.2 \mathrm{~mm}$ is the sample which proper to following electron beam irradiation treatment (Fig. 1d).

\section{Molecular weight measurement}

Each type of powder methylcellulose was weighed as much $0.02 \mathrm{~g}$, then dissolved in water to a volume of $100 \mathrm{~mL}$ at room temperature and stirred until completely dissolved. The viscosity of solution was determined by using ubbelohde viscometer type at a temperature of $20{ }^{\circ} \mathrm{C}$ respectively. Some of viscosity measurements were carried out by diluting the initial solution concentration in order to determination of its molecular weight (Mv). Determination of methylcellulose $\mathrm{Mv}$ was performed according to standard methods of United Standard Pharmacopeia (USP).

\section{Gel fraction determination}

Gel fraction defined as the mass fraction of the network materials that forming from a crosslinking process, which caused it not soluble in water. Each sample film was taken of two (2) pieces of $1 \mathrm{~cm} \times 1 \mathrm{~cm}$ size, the first piece put into an oven at $80{ }^{\circ} \mathrm{C}$ for $24 \mathrm{~h}$, then weighed as dry gel $\left(\mathrm{W}_{\mathrm{o}}\right)$. The second film piece wrapped by using a 200 mesh steel wire sieve and immersed in water at room temperature while shaken for $24 \mathrm{~h}$, dried in oven at $80{ }^{\circ} \mathrm{C}$ for $24 \mathrm{~h}$, and finally weighed as $W_{d}$. The gels fraction is amount percent of gel is not soluble in water during immersed, which can be formulated as follows [9]:

Gels fraction $=\frac{W_{d}}{W_{o}} \times 100 \%$

where,

$W_{0}=$ initial dry gel weight, $g$

$\mathrm{W}_{\mathrm{d}}=$ dry gel weight after dissolution, $\mathrm{g}$

\section{Degree of swelling/DS}

Degree of swelling is defined as the ratio of the weight of the swollen gel decided by weight of dry gel. It can be determined by cutting the film gels in a size of 1 $\mathrm{cm} \times 1 \mathrm{~cm}$, then removed it's plastic packaged and dried on $80^{\circ} \mathrm{C}$ for $24 \mathrm{~h}$, then weighed as dry weight, $\mathrm{W}_{\mathrm{d}}$. The second piece is dissolved in water allowed to stand overnight, then gel was taken and the surface wiped with tissue paper, and then weighed as the swollen weight, $W_{s}$. The degree of swelling can be calculated as formulated [9]:

$\mathrm{DS}=\frac{\mathrm{W}_{\mathrm{s}}}{\mathrm{W}_{\mathrm{d}}} \times 100 \%$

where,

$W_{s}=$ the swollen weight of the gel, $g$

$\mathrm{W}_{\mathrm{d}}=$ weight of dry gel, $\mathrm{g}$

\section{Tensile strength (TS) and elongation at break (EB) properties}

These TS and EB properties are done simultaneously; the hydrogel film samples were cut by using a dumbbell cutter of ASTM D 412 series in several pieces, and then tested with an Instrons tensile tester of Stograph-R1 Toyoseiki. Test specimens of ASTM D 412 series having a certain shape, with a width of $0.3 \mathrm{~cm}$ and the distance of stretchy part is 1 $\mathrm{cm}$. The amount load $(\mathrm{kg})$ in determination of these physical properties was indicated by a number or scale on the graph paper shows the load causes the sample has broken. The tensile strength of sample can be calculated by the following equation [9]:

$\mathrm{TS}=\frac{\mathrm{F}}{\mathrm{L} \times \mathrm{t}}$

where,

$\mathrm{F}=$ breaking loads, $\mathrm{kg}$

$\mathrm{L}=$ wide of breaking area, $0.3 \mathrm{~cm}$

$\mathrm{t}=$ the thickness of hydrogel films, $\mathrm{cm}$

For the elongation at break, EB:

$E B=\frac{L_{b}}{L_{o}} \times 100 \%$

where,

$L_{b}=$ the specimen length at breaking, $\mathrm{cm}$

$L_{o}=$ the initial length of specimen test, $\mathrm{cm}$

\section{RESULT AND DISCUSSION}

According to Wach, [4], water is the best solvent for cellulose and its derivatives, because it can be directly interaction in solution through its hydrophilicity and formed hydrogen bonds with the-OH groups of methylcellulose substituents. The measurement results of their viscosities and determined molecular weight/Mv, shown in the Table 1.

After irradiation, all the SM-4 gels concentration of 15,20 , and $30 \%$ were dissolved in water, which is indicate that crosslinking does not occurred. This phenomenon shows that there are no crosslinked of SM-4 gels, due to low of its molecular weight [4]. Relating to Joseph [10], in the water-methylcellulose 
Table 1. Mv

\begin{tabular}{clcc}
\hline No & Sample & Intrinsic viscosity, $\eta$ & $\mathrm{Mv}, \mathrm{g} / \mathrm{mol}$ \\
\hline 1 & SM-4 & 0.75 & $2.10 \times 10^{4}$ \\
2 & SM-100 & 3.05 & $2.67 \times 10^{4}$ \\
3 & SM-400 & 7.73 & $1.45 \times 10^{4}$ \\
4 & SM-4000 & 8.02 & $1.55 \times 10^{4}$ \\
5 & SM-8000 & 8.68 & $1.79 \times 10^{4}$ \\
\hline
\end{tabular}
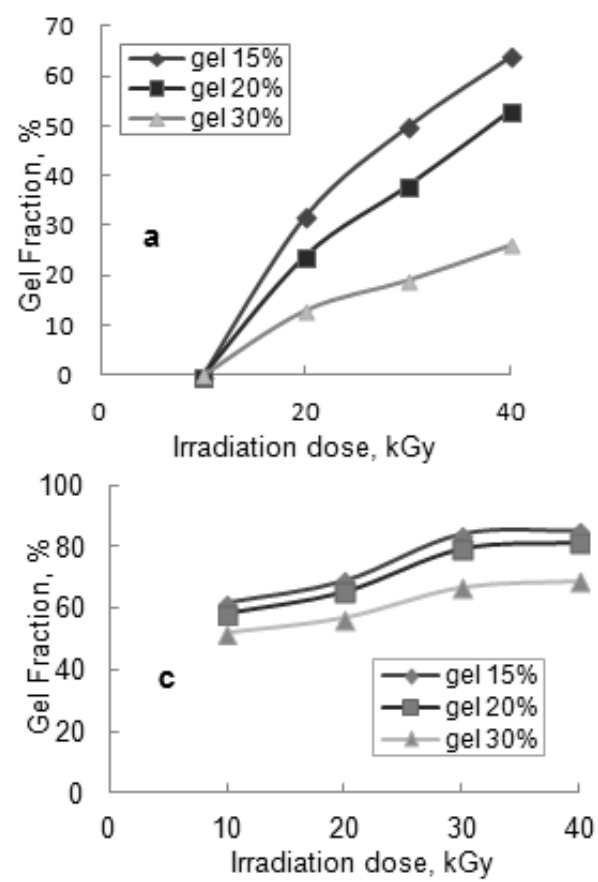
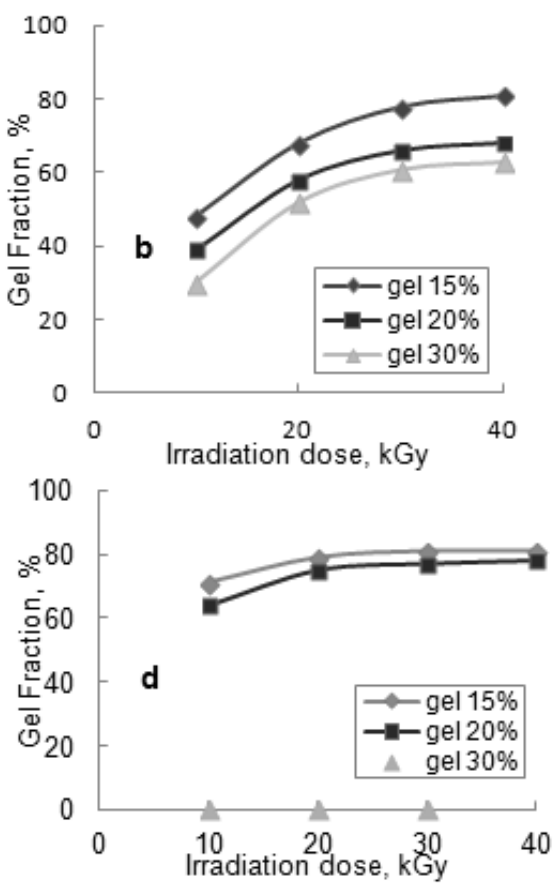

Fig 2. Gel fraction vs. irradiation dose of: a. SM-100 gels, b. SM-400, c. SM-4000, and d. SM-8000 gels

solution system with Mv higher than $300,000 \mathrm{~g} / \mathrm{mol}$ has been able to form a transparent gel in the presence of methylcellulose fibers dispersed in aqueous media. Gel with zero of gel fraction is mean gel without crosslinking material, where gel fraction is a parameter which is responsible to its physical properties. According to Sarawut, [3] ionizing radiation process of methylcellulose with the concentration more than $7 \%$ leading to crosslink, which leads to the formation of macroscopic, insoluble material.

Fig. 2 are shows the curves of gel fraction versus irradiation dose of SM-100, SM-400, SM-4000 and SM8000 methylcellulose gels respectively. The curves show that percent gel fraction for all concentrations were increase with increasing of doses irradiation, and then decreases with increasing of concentrations.

Refer to Rosiak [11], that the gel fraction increased with increasing of dose, but in some cases the gel fraction decreased after reaching a maximum as shown at Fig. 2c. The optimum gel fraction is affected by molecular weight, gel concentration and radiation dose, which is for higher of molecular weight, the greater of optimum dose is needed on the same concentration. Four graphs shown that gel fraction reaches an average of 60 to $80 \%$ which were obtained from a dose a range of 20 30 kGy, except of SM-8000 (Fig. 2d) which obtained as the hard gels, let alone for $30 \%$ concentration, so the gel fraction can't be accounted in the measurement.

Generally, seen with increase in dose irradiation and gel concentration hence the swelling ratio appears to decrease (Fig. 3), this is in accordance to Yang [12], that the gel formed with high concentrations will possess higher gel fraction causing a decrease in the distance between the crosslink points, and caused lowering the swelling ratio. In the swollen state of gels, the water were trapped in a three-dimensional network between crosslink site (Fig.1b), [3] and by gel fraction impact indicating the fact that gel fraction is the deciding factor for controlling the swelling ratio. In the term the effect of $\mathrm{Mv}$ on the swelling ratio, such as Fig. $3 a$ as compared to that of $3 b$, Fig $3 c$ and further, there are seen with increasing of Mv gels the swelling ratio will decrease. Similar results were reported by Bajpai [13] that by increasing of $\mathrm{Mv}$, the hydrogel-water affinities is also reduced which in turn will affect its on decreasing of swelling ratio. The results showed that the average swelling ratio of SM-100, SM-400 and 

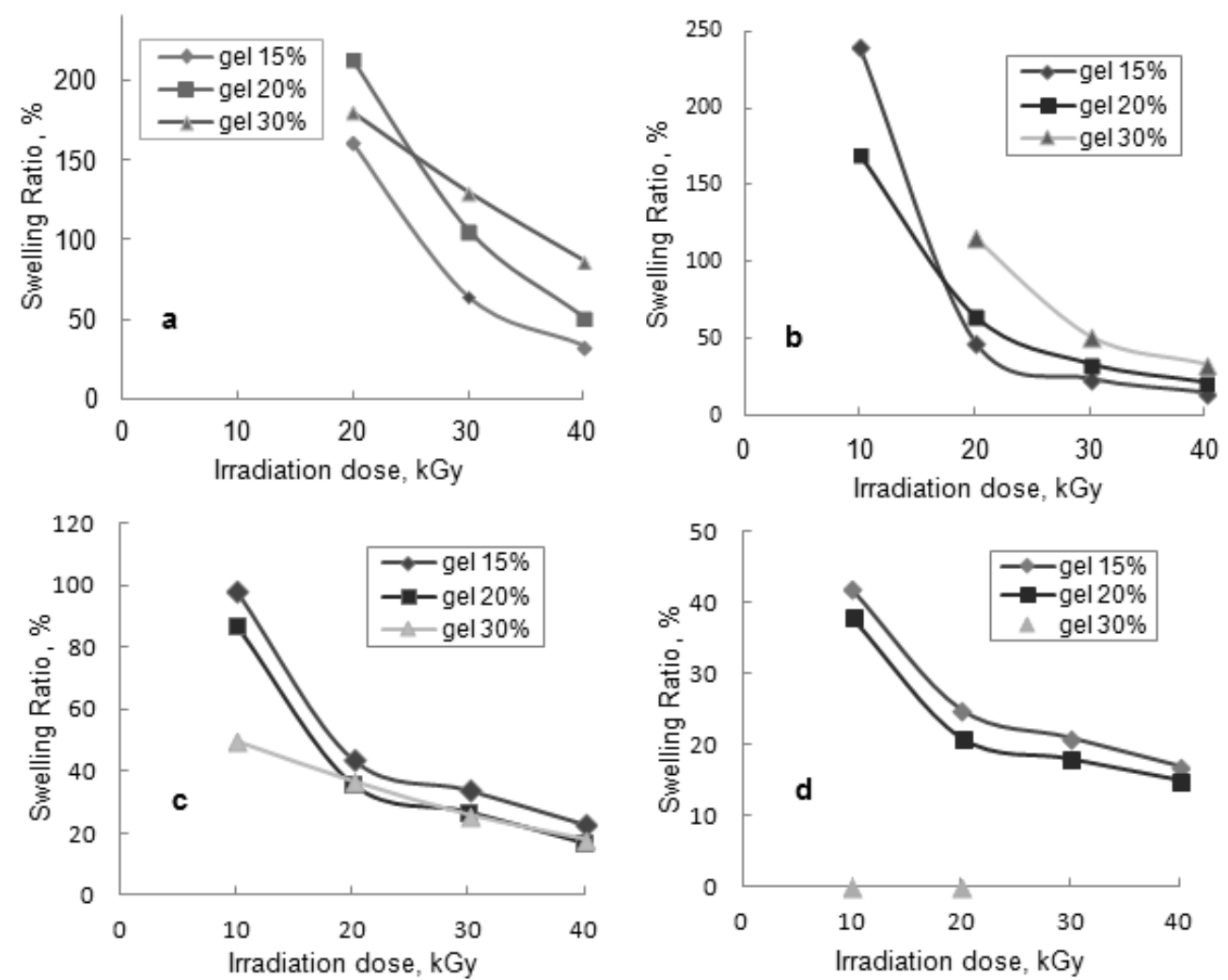

Fig 3. Swelling ratio vs. irradiation dose of: a. SM-100, b. SM-400, c. SM- 4000 , and d. SM- 8000 gels
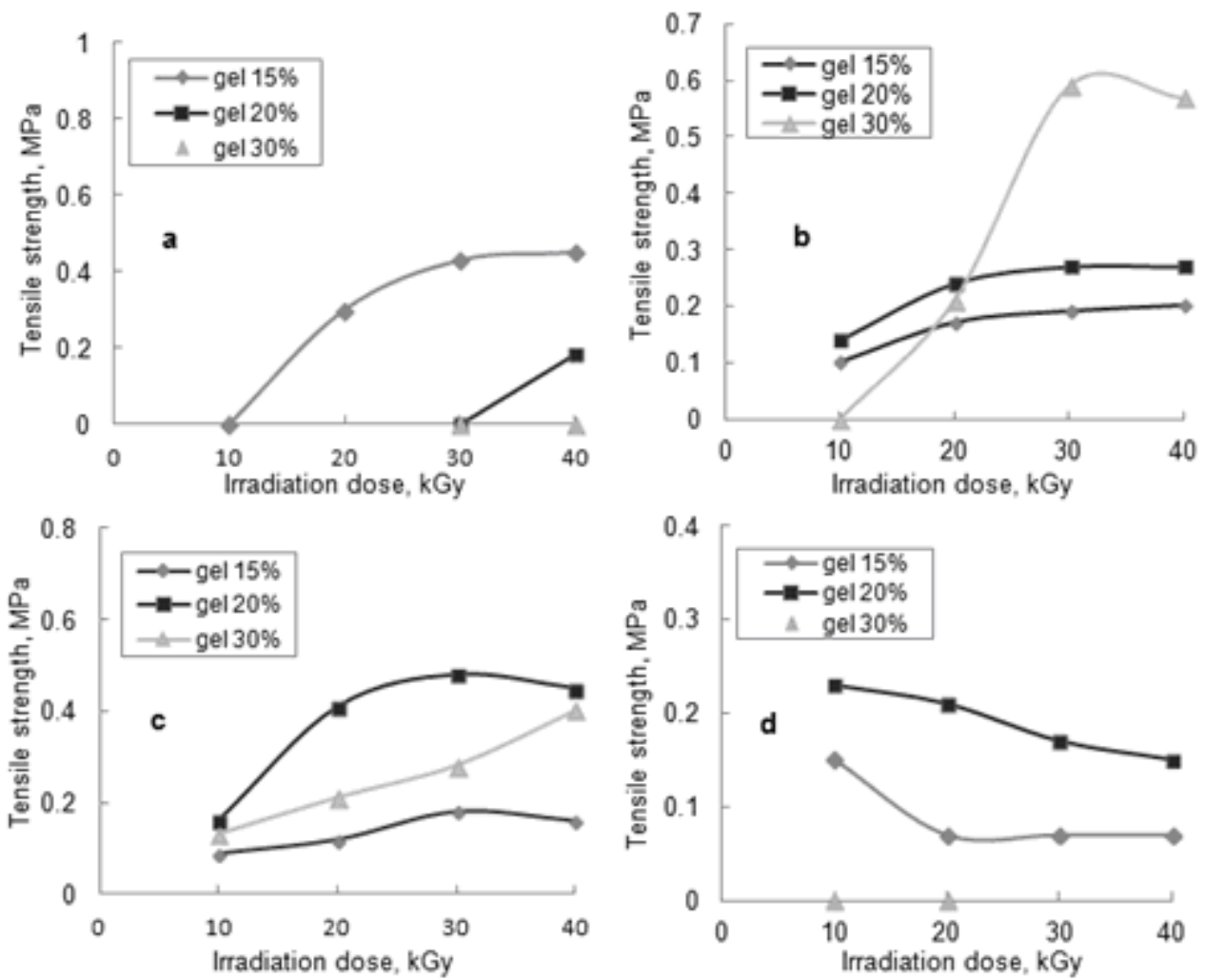

Fig 4. Tensile strength vs. irradiation dose of: a. SM-100, b. SM-400, c. SM-4000, and d. SM-8000 gels 

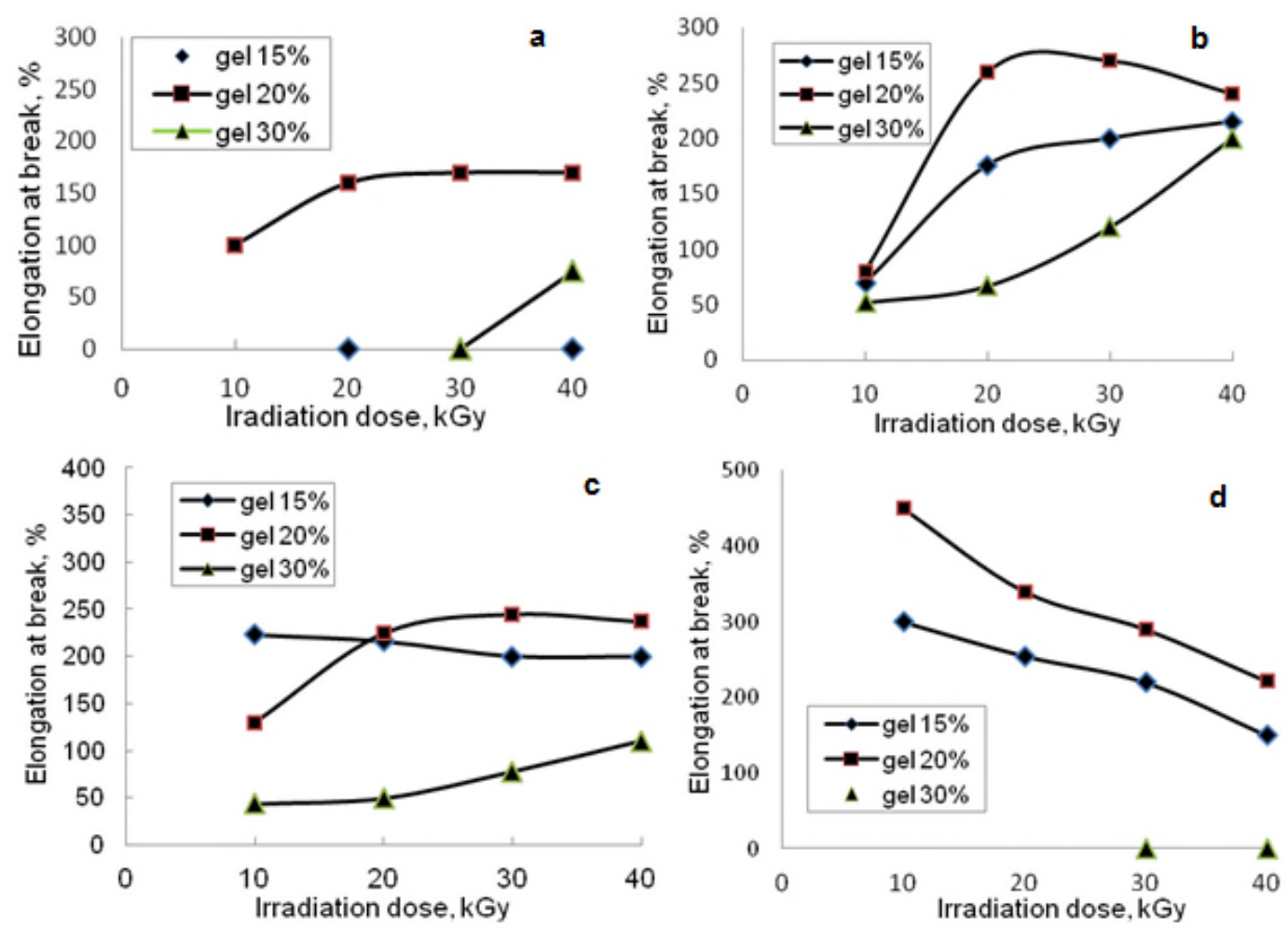

Fig 5. Elongation at break vs. irradiation dose of: a. SM-100, b. SM-400, c. SM-4000, and d. SM-8000 gels

SM-400 gels reaches $50 \%$ to $250 \%$ respectively, by the irradiation dose up to $30 \mathrm{kGy}$. On the other, Abdurrahmanoglu [14] suggested that gels with high swelling ratio (up to $400 \%$ ) are the weak gel which lower of elasticity and gave a limited influence on their application areas.

Mechanical tests, such as tensile strength were conducted to assess the hydrogel properties. To establish a data base of tensile strength of hydrogels is to gather the information of the hydrogel network and to determine the suitability of the wound dressing application. The tensile strength curves in Fig. 4a to 4c in generally, exhibited an increase in tensile strength with increasing of irradiation dose, whereas the curves of Fig. 4d deviated from the main trend.

With increase of Mv, refer to Fig. 4a as compared to Fig. 4b and Fig. 4c, the tensile strength of all gel types seem to be affected to come down for the same gel concentration. This phenomenon has also been revealed by Bajpai [13] that gel with high Mv, resulting water-gel affinity is reduced so that the physical strength decreases. In review of each curve, there are seen that the increase in the irradiation doses will give effect to the increase of tensile strength. This was confirmed by Wach [15], that gel with the larger of Mv, crosslinking effect is more dominant than of degradation, although it only takes place in a certain range of dose variation. The result of gel curves of medium methylcellulose $\mathrm{Mv}$ that is SM-100, SM-400 and SM-4000 reaches by 0.2 to 0.55
$\mathrm{MPa}$ of tensile strength, which obtained by dose range of 15 to $20 \mathrm{kGy}$. In its application as a wound dressing, the tensile strength is needed in order to shore up its physical impact of the activities of the wearer.

Refers to the curve on Fig. $4 \mathrm{~d}$, that shows the tensile strength of gels with highest of $\mathrm{Mv}$, which apparent decrease in tensile strength with increasing of both gel concentration and irradiation dose is suspected due to the effects of gel-water affinities [14]. Recently, the gels of SM- 8000 at concentration of $20 \%$ and $30 \%$ are in the form of the hard gels and these are not feasible for wound dressing's application.

Elasticity of the gels which is represented by the elongation at break Fig. $5 \mathrm{a}$ up to $5 \mathrm{~d}$, in general the curves appears to rise at a certain dose range (20-30 $k G y$ ), which is similar to their tensile strength curves. Referring to preview such SM-100 gels as compared to that of SM-4000, in the term of same concentration and dose irradiation, the gel with higher $\mathrm{Mv}$ will have the greater of elongation at break, and the similarly tendency for SM-4000 and SM-8000 gels respectively. In accordance with the state of Abdurrahmanoglu [14], the polymer chain length directly plays a key role for the elongation at break properties, while by Wach [15] that the decrease in elongation at break in highest dose irradiation due to degradation of the gels through polymer gel chain scission.

Especially in Fig. 5d review gel with of very high Mv (SM-8000), appear the curve decreases with 
increasing of irradiation dose, even for it of $30 \%$ concentration produced very hard gels. Related with Bajpai [13], gels with the higher of $\mathrm{Mv}$, the solution viscosity will decrease and causing a weak of water-gel affinities, consequently lower of its physical properties.

\section{CONCLUSION}

In the present study, methylcellulose gels of some kind of Mv have been made succesfully by using electron beam irradiation. On the lower Mv (SM-4) the gels are not formed due to weak of intermolecular crosslink force, while more dominant of degradation process. The gels with physical conditionally and good appearance were obtained from the methylcellulose of medium Mv viz. SM-100, SM-400 and SM-4000 on the concentration of 15 and $20 \%$ respectively, by controlling the optimum dose at around $20 \mathrm{kGy}$. It was suggested that gel with the type of $\mathrm{Mv}$, composition and radiation dose mentioned above is proposed as wound dressings material.

\section{ACKNOWLEDGEMENT}

The author gratefully acknowledges for Mr. Yamaguchi K. the staff of JAEA Takasaki, Japan which perform in the treatment of electron beam irradiation during this research was conducted.

\section{REFERENCES}

1. Anonymous, http://en.wikipedia.org/wiki/Methylcellu lose, accessed on January 2014.

2. Sannino, A., Demitri, C., and Madaghiele, M., 2009, Materials, 2 (2), 353-373.

3. Rimdusit, S., Somsaeng, K., Kewsuwan, P., Jubsilp, C., and Tiptipakorn, S., 2012, Eng. J., 16 (4), 2-14.

4. Wach, R.A., Mitomo, H., Nagasawa, N., and Yoshii, F., 2003, Nucl. Instrum. Methods Phys. Res., 211 (4), 533-544.
5. Anonymous, http://us.elsevierhealth.com/.../978075 0688079.p., Wound dressings and BandagesElsevier, accessed on February 2014.

6. Weller, C., and Sussman, G., 2006, J. Pharm. Pract. Res., 36, (4), 318-324.

7. Zahedi, P., Rezaeian, I., Ranaei-Siadat, S-O., Jafari, S-H., and Supaphol, P., 2010, Polym. Adv. Technol., 21 (22), 77-95.

8. Anonymous, http://en.wikipedia.org/wiki/Ubbeloh de_ viscometer, accessed on January 2014.

9. Suliwarno A., 2009, Jaringan Kerjasama Kimia Indonesia, Yogyakarta, 339-342.

10. Lott, J.R., McAllister, J.W., Arvidson, S.A., Bates, F.S., and Lodge, T.P., 2013, Biomacromolecules, 14 (8), 2484-2488.

11. Rosiak, J.M., Janik, I., Kadlubowski, S., Kozicki, M., Kujawa, P., Stasica, P., and Ulanski P., 2002, "Radiation Formation of Hydrogels for Biomedical Application" in Radiation Synthesis and Modification of Polymers for Biomedical Applications, IAEA-TECDOC-1324, Vienna-Austria, 5-47.

12. Yang, F., Li, G., He, Y-G., Ren, F-X., and Wang, GX., 2009, Carbohydr. Polym., 78 (1), 95-99.

13. Bajpai, A.K., and Giri, A., 2002, React. Funct. Polym., 53 (2-3), 125-141.

14. Abdurrahmanoglu, S., Can, V., and Okay, O., 2009, Polymer, 50 (23), 5449-5455.

15. Wach, R.A., Mitomo, H., Kudoh, H., Muroya, Y., Katsumura, Y., and Yoshii, F., 2005, Proceeding of the $8^{\text {th }}$ Polymers for Advanced Technologies International Symposium, Budapest, Hungary, 1316.

16. Ahmed, E.M., 2013, J. Adv. Res., DOI: 10.1016/j.jare.2013.07.006.

17. Rinaudo, M., 2010, Polymers, 2 (4), 505-521.

18. Patel, T.R., Morris, G.A., de la Torre, J.G., Ortega, A., Mischnick, P., and Harding, S.E., 2008, Macromol. Biosci., 8 (12), 1108-1115.

19. Suliwarno, A., 2013, Indo. J. Mater. Sci., 15 (1), 40-44. 